ТЕОРЕТИЧНЕ ОБҢРУНТУВАННЯ МОДЕЛІ

ПСИХОЛОГІЧНОГО СУПРОВОДУ СТАРШИХ ДОШКІЛЬНИКІВ

ІЗ ПОРУШЕННЯМИ ІНТЕЛЕКТУАЛЬНОГО РОЗВИТКУ

\title{
THEORETICAL SUBSTANTIATION OF THE MODEL OF PSYCHOLOGICAL SUPPORT OF SENIOR PRESCHOOLERS WITH INTELLECTUAL DEVELOPMENT DISORDERS
}

УдК 376-056.36:37.013.77:005.336.2 DOI https://doi.org/10.32843/26635208.2020.18.2.24

\section{Чобанян А.B.}

к.психол.н.,

старший викладач кафедри спеціальної та інклюзивної освіти

Сумський державний педагогічний університет імені А.С. Макаренка

Колишкіна А.П.

к.пед.н.

доцент кафедри дошкільної і початкової освіти

Сумський державний педагогічний

університет імені А.С. Макаренка у статmі зосереджено увагу на обгрунтуванні складників теоретичної моделі психологічного супроводу старших дошкільників із порушеннями інтелектуального розвитку помірного ступеня. На думку авторів, особливого значення психологічний супровід дітей зазначеної категорії набуває під час їхнього вступу до школи, адже саме від сорормованості у дитини готовності до навчання в школі залежить якість їі освіти загалом. В цьому аспекті надвразливими $\epsilon$ старші дошкільники із порушеннями інтелектуального розвитку помірного ступеня, оскільки їхнє основне ураження унеможливлює природний процес самостійного напрацювання патернів поведінки, що забезпечують їхнє ефективне адаптування до умов шкільного навчання як нової соціальної ситуації розвитку. Звідси виникає потреба в розробленні й упровадженні дієвої системи психологічного супроводу, що забезпечуватиме розвиток і формування механізмів адаптування старших дошкільників із порушеннями інтелектуального розвитку до подальшого шкільного навчання.

Авторами статті на основі теоретико-методичних засад психологічного супроводу теоретично обірунтовано й розроблено модель психологічного супроводу дітей старшого дошкільного віку з порушеннями інтелектуального розвитку помірного ступеня, що містить такі складники: науковий, що визначає наукові підходи, принципи, функції; цільовий, що конкретизує мету і завдання здійснення супроводу; організаційно-процесуальний, що містить умови, фрорми, методи, етапи психологічного впливу на процес формування соціальної готовності; результативний для оцінювання ефрективності прочесу формування. Встановлено, що організація психологічного супроводу має відповідати специфріці категорії тієї особистості, на допомогу якої він спрямований, що обгрунтовує доцільність емпіричного виявлення особливостей сорормованості у дітей 3 інтелектуальними порушеннями помірного ступеня основного утворення старшого дошкільного віку - соціальної готовності.
Ключові слова: психологічний супровід, порушення інтелектуального розвитку, старші дошкільники, готовність до навчання в школі.

The authors of the article based on the theoretical analysis of scientific sources found that the psychological support of children of different ages provides the child with support and assistance in solving specific difficulties of its psychosocial development, which naturally occur at each stage of ontogenesis. At the stage of transition of children from preschool to school, it is fundamental to address the issue of forming their social readiness to study at school to ensure the success of their adaptation to the new social situation of development.

The authors of the article on the basis of theoretical and methodological principles of psychological support theoretically substantiates and develops a model of psychological support of older preschool children with intellectual disabilities of moderate degree, containing such components as: scientific, which defines scientific approaches, principles, functions; target, specifying the purpose and objectives of support; organizational and procedural, containing conditions, forms, methods, stages of psychological influence on the process of formation of social readiness; effective for evaluating the effectiveness of the formation process. According to the results of theoretical analysis, the meaning of psychological support is defined as a type of professional activity of a practical psychologist, which provides the subjects of educational space with a range of psychological services aimed at creating favorable conditions for social readiness for children with moderate intellectual disabilities at school. It is established that the organization of psychological support should meet the specifics of the category of the person to whom it is aimed, which justifies the feasibility of empirical identification of the peculiarities of formation in children with moderate intellectual disabilities of the main stage of senior preschool age - social readiness.

Key words: psychological support, intellectual development disorders, senior preschoolers, readiness to study at school.
Постановка проблеми. На цей час система спеціальної та інклюзивної освіти - це не лише мережа освітніх закладів, де здійснюється процес навчання й виховання дітей 3 порушеннями психофізичного розвитку, але й система соціальної, психологічної підтримки і допомоги, комплексного супроводу цих осіб на різних вікових етапах, що забезпечує їх освіту, соціальну адаптацію та інтеграцію в суспільство.
Підкреслимо, що останнім часом суттєво зросла зацікавленість провідних науковців країни та практиків галузі спеціальної та інклюзивної освіти щодо проблеми допомоги дітям із вираженим ступенем інтелектуального порушення - дітям із порушеннями інтелектуального розвитку помірного ступеня (далі - ПІР ПС). Психологічний супровід зазначеної категорії дітей є однією з провідних умов організації корекційно-розвиваючої роботи з ними. 
Особливе значення організація й впровадження психологічного супроводу дітей зазначеної категорії набуває під час вступу до школи, адже саме від сформованості у дитини готовності до навчання в школі залежить якість ії освіти загалом. В цьому аспекті надвразливими є старші дошкільники із порушеннями інтелектуального розвитку помірного ступеня, оскільки їхнє основне ураження унеможливлює природний процес самостійного напрацювання патернів поведінки, що забезпечують їхне ефективне адаптування до умов шкільного навчання як нової соціальної ситуації розвитку. Звідси виникає потреба в розробленні й упровадженні дієвої системи психологічного супроводу, що забезпечуватиме розвиток і формування механізмів адаптування старших дошкільників із порушеннями інтелектуального розвитку до подальшого шкільного навчання.

Аналіз останніх досліджень та публікацій. Визначення психологічного супроводу в контексті корекційної психопедагогіки пропонують С. Миронова, О. Гаврилов та М. Матвєєва [6]. Дослідники вважають, що психологічний супровід дитини з особливостями психофізичного розвитку - це взаємоузгоджена комплексна діяльність мультидисциплінарної команди фахівців і батьків дитини, спрямована на створення необхідних умов, що сприяють розвитку особистості дитини; засвоєнню нею знань, умінь і навичок; успішній адаптації, реабілітації; іï самореалізації та інтеграції в соціум [6, с. 69].

Особливу увагу приділяємо трактуванню поняття «психологічний супровід» такими провідними вітчизняними науковцями у галузі спеціальної психології, як Т. Сак, В. Кобильченко, Т. Калініна, В. Соколов, Г. Соколова. Зокрема, Т. Сак розглядає психологічний супровід як процес діагностики та корекції психічного розвитку дитини. При цьому відстежуються не лише особливості дизонтогенезу, але й збереження компоненту психічної сфери, який слугуватиме підґрунтям для компенсації у процесі цілеспрямованого корекційного впливу [7, с. 16-19].

Особливу зацікавленість викликають наукові праці дослідника В. Кобильченка, присвячені психологічному супроводу. Науковець визначає в структурі психологічного супроводу два компоненти: психологічну підтримку та психологічну допомогу. Ці два компоненти психологічного супроводу перебувають у тісній неподільній єдності, взаємній детермінації та впливають один на одного. Якщо психологічна підтримка покликана попереджувати виникнення психологічних проблем і конфліктів у сфері соціальної взаємодії та на шляху особистісного становлення підлітка, то психологічна допомога $є$ допомогою психолога людині в нормалізації її психоемоційних ста- нів, корекції Я-образу та соціальних установок щодо інших людей, у розв'язанні психологічних проблем і труднощів особистісного зростання, соціальної взаємодії [4].

У наукових працях Т. Калініної представлено модель психологічного супроводу молодших підлітків із ЗПР та розроблено програму супроводу щодо формування соціально-психологічної компетентностіпідлітків. Дослідниця визначає феномен психологічного супроводу як вид професійної діяльності практичного психолога з формування й корекції особистості, психологічної підтримки й допомоги дитині в адаптації до нових умов життєдіяльності, попередженні й вирішенні її психологічних проблем [3]. Визначаючи теоретико-методичні засади психологічного супроводу школярів із синдромом Дауна, Г. Соколова розглядає психологічний супровід як багатомірну систему комплексної психологічної підтримки та допомоги дітям із синдромом Дауна та їхнім батькам, яка включає в себе різні форми, методи і засоби допомоги в процесі навчання та позанавчальної життєдіяльності, підвищення резистентності дітей до дестабілізуючих зовнішніх та внутрішніх факторів. Дослідницею розроблено систему психологічного супроводу як соціальної підтримки та психологічної допомоги школярам із синдромом Дауна [8].

Отже, проаналізувавши загальну та спеціальну науково-методичну літературу, під психологічним супроводом розуміємо систему заходів, спрямованих на створення сприятливих умов для розвитку дитини старшого дошкільного віку із ПІРПС уаспекті формування соціальної готовності до навчання в школі. Суб'єктами створення сприятливих умов для розвитку дитини виступають: сім'я дитини старшого дошкільного віку з ПІР ПС і психолог закладу дошкільної освіти. Доцільність залучення сімей до психологічного супроводу дітей з особливими потребами зумовлена тим фактом, що родина $€$ першою й головною соціальною групою, яка активно впливає на фізичний, психічний і соціальний розвиток дитини дошкільного віку. Тому в процесі розробки теоретичної моделі психологічного супроводу під учасниками супроводу розуміємо «агентів» $\mathrm{i}$ «клієнтів» супроводу. Агентом психологічного супроводу виступає психолог, а клієнтами супроводу є діти старшого дошкільного віку з ПІР ПС та їх батьки. Вважаємо, що залучення батьків до реалізації психологічного супроводу дітей зазначеної категорії позитивно позначиться на розвитку компетентностей у батьків або осіб, які їх заміщують.

Відтак для більш ширшого розуміння реалізації психологічного супроводу дітей старшого дошкільного віку з ПІР ПС у контексті формування в дітей зазначеної категорії соціальної готовності до навчання, звернімося 
до розробки теоретичної моделі психологічного супроводу. Це надасть змогу перевірити на практиці точність теоретичних уявлень про психологічний супровід, а також надасть змогу визначити зміст супроводу в практичній діяльності фахівців галузі спеціальної та інклюзивної освіти.

Відповідно до психологічного словника під моделлю розуміється спрощений уявний або знаковий образ якого-небудь об'єкта або системи об'єктів, застосовуваний як їх «заступник» чи засіб оперування [5]. Філософський словник визначає модель, як аналог (схема, структура, знакова система) певного фрагмента природної або соціальної реальності, породження людської культури, концептуально-теоретичного утворення - оригіналу моделі. Вона призначена для збереження й розширення знань (інформації) про оригінал, конструювання оригіналу, перетворення чи керування ним. В основі системи психологічного супроводу повинна бути модель, що є єдністю структурних елементів, які використовуються й зорієнтовані на зміст проблем розвитку дитини з помірною розумовою відсталістю в первинному та вторинному інститутах соціалізації. Проте в системі спеціальної дошкільної освіти подібна модель не використовується, а психологічний супровід здійснюється не у вигляді цілісних програм, а фрагментарно, що в принципі недопустимо, коли йдеться про соціальний розвиток старшого дошкільника з помірною розумовою відсталістю.

Теоретико-методологічний аналіз літературних джерел переконливо свідчить, що на сьогоднішній день саме супровід виступає особливою формою здійснення пролонгованої соціальної та психологічної допомоги [1]. Поділяємо погляди науковців стосовно того, що супровід передбачає не виправлення недоліків, а пошук прихованих ресурсів розвитку дітей із ПІР ПС і подальшу опору на них у процесі навчання й виховання. Підтвердженням доречності реалізації супроводу саме як системи допомоги дітям із ПІР ПС у аспекті формування готовності до навчання $€$ розуміння супроводу як «постійної підтримки оптимальної адаптованості дитини до освітнього середовища» [2]. Автор трактує супровід як двосторонній процес пристосування дитини до освітнього середовища й, відповідно, середовища до можливостей дитини - взаємоадаптацію, яка є головною характеристикою комплексного супроводу дитини старшого дошкільного віку з порушеннями інтелектуального розвитку помірного ступеня (далі - СДВ із ПІР ПС). Дослідження наукової літератури дозволяє стверджувати, що питання психологічного супроводу дітей СДВ із ПІР ПС $є$ актуальним, проте відсутнє єдине трактування. Спираючись на теоретичні підходи щодо тлумачення змісту поняття «психологічний супро- від», ми сформулювали визначення дефініції «психологічний супровід дітей СДВ із ПІР ПС»вид професійної діяльності практичного психолога, який передбачає надання суб'єктам освітнього простору комплексу психологічних послуг, спрямованих на створення сприятливих умов для формування соціальної готовності до навчання дітей з порушеннями інтелектуального розвитку помірного ступеня в школі.

Постановка завдання. Метою статті $€$ теоретичне обґрунтування складників моделі психологічного супроводу дітей старшого дошкільного віку з порушеннями інтелектуального розвитку помірного ступеня з метою формування соціальної готовності до навчання в школі.

\section{Виклад основного матеріалу дослі-} дження. $y$ процесі розробки моделі ми виходили з того, що теоретична конструкція повинна містити всі основні компоненти, властиві будь-якій психолого-педагогічній теорії: мету, завдання, принципи, учасників, етапи роботи, які зумовлюють змістове наповнення моделі психологічного супроводу, та наявність структурних елементів, що забезпечують ефективність роботи, надають моделі функціональних ознак як системі. Теоретична модель призначена для відображення змісту психологічного супроводу дітей із ПІР ПС в аспекті формування соціальної готовності до навчання в школі, а також його принципів, цілей і способів здійснення (рис. 1).

Так, у процесі розробки моделі психологічного супроводу дітей старшого дошкільного віку з порушеннями інтелектуального розвитку помірного ступеня ми враховували соціальну ситуацію розвитку й ті цілі та завдання, які ставить суспільство перед спеціальними дошкільними й загальноосвітніми навчальними, інклюзивними закладами (гуманізація, демократизація, індивідуалізація). Ураховуючи специфіку індивідуальних і вікових особливостей дітей старшого дошкільного віку, у модель нами було включено такі складники психологічного супроводу, як науковий (наукові підходи, принципи, функції), цільовий (мета, завдання), організаційно-процесуальний (експериментальні моделі, умови, форми, методи, етапи), результативний (проміжний результат, результат).

Схарактеризуємо наповнюваність теоретичної моделі психологічного супроводу. Оскільки в реалізації психологічного супроводу задіяні фахівці галузі спеціальної освіти й батьки (або особи, які їх заміщують) дітей із ПІР ПС старшого дошкільного віку, у процесі розробки його наукового складника було взято до уваги такі принципи:

- добровільності в прийнятті допомоги, активноїучасті сім'ї-повагидо дитини, визнання іï цінності незалежно від реальних досягнень 


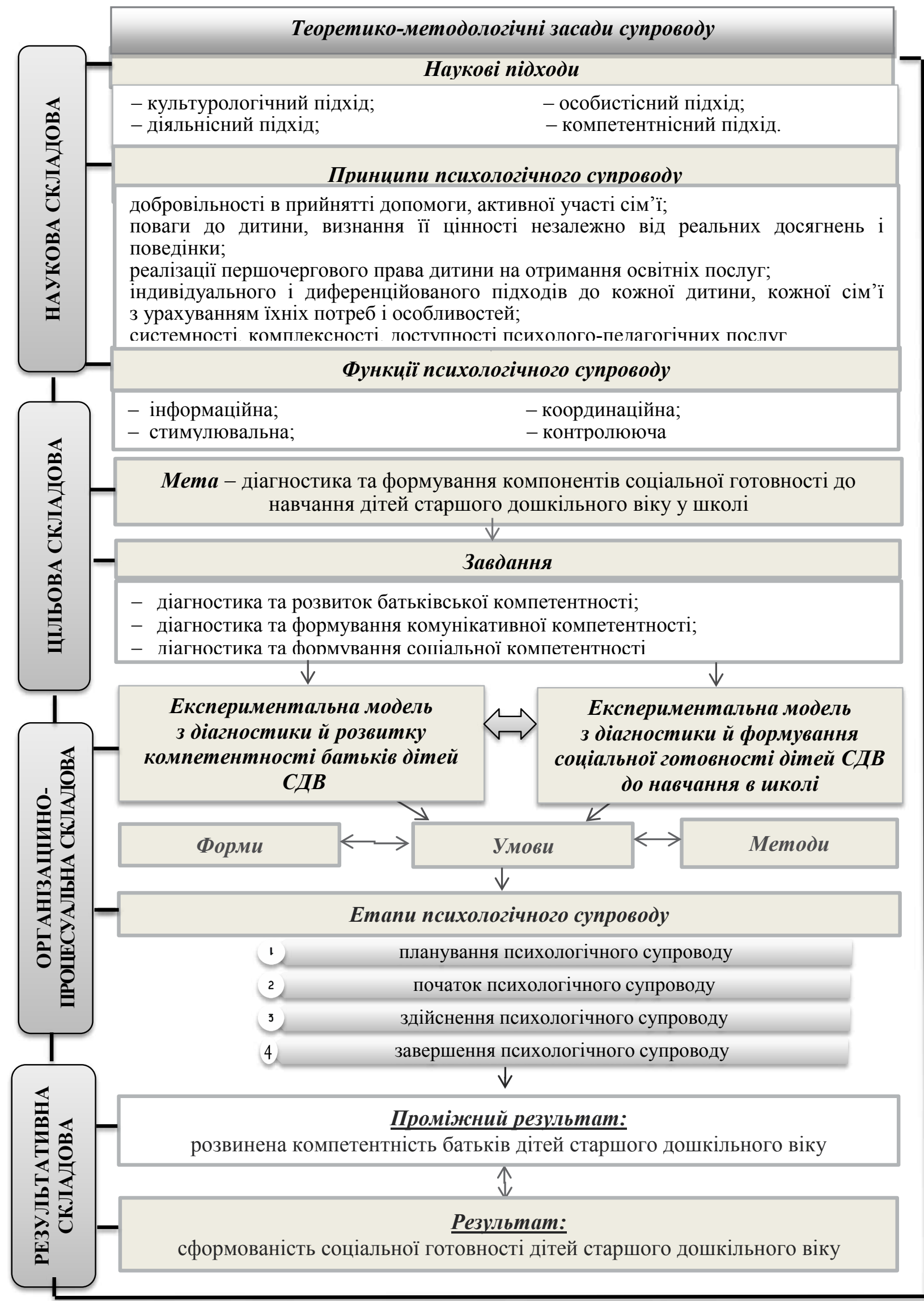

Рис. 1. Модель психологічного супроводу старших дошкільників щодо формування соціальної готовності до навчання 
і поведінки. Цей принцип передбачає побудову психологічного супроводу, заснованого на пріоритеті загальнолюдських цінностей, життя та здоров'я дитини та сприяє формуванню в неї відчуття власної значущості й цінності, свободи вибору можливостей розвитку особистості;

- реалізації першочергового права дитини на отримання освітніх послуг. У ньому наголошується на забезпеченні альтернативних можливостей для здобуття освіти відповідно до індивідуальних потреб і особливостей психофізичного розвитку;

- індивідуального й диференційованого підходів до кожної дитини, кожної сім'ї з урахуванням їхніх потреб і особливостей. Індивідуалізація корекційної роботи передбачає за потреби забезпечення єдності педагогічного, психологічного, логопедичного, фізично-реабілітаційного та медичного впливів на дитину та її батьків в оптимальних поєднаннях із дотриманням послідовності й наступності;

- системності, комплексності, доступності психолого-педагогічних послуг. Він зумовлений особливостями розвитку дитини. Розвивальне середовище має за мету запропонувати дитині із ПІР ПС матеріал для її якомога активної участі в різних видах діяльності, а вибір дитини можливий лише за умови, коли перед нею будуть доступні предмети.

Цінність психологічного супроводу полягає в тому, що він виконує низку функцій, які притаманні психолого-педагогічній роботі з дітьми з порушеннями інтелектуального розвитку та їх сім'ями. Провідними є такі з них:

- інформаційна (спрямована на надання батькам необхідної інформації з конкретних питань щодо освітніх послуг, розвитку й виховання дітей);

- стимулювальна (виражається в підтримці тих позитивних особистісних новоутворень у дітей, що є необхідними для успішного формування соціальної готовності до навчання);

- діагностична (спрямована на виявлення рівня сформованості соціальної позиції та проблемних моментів щодо формування соціальної готовності до навчання);

- навчально-консультативна (орієнтована на поглиблення знань, розвиток навичок і вмінь батьків, що необхідні для формування соціальної готовності дітей до навчання; ліквідація напруженості взаємодії батьків із фахівцями галузі спеціальної освіти);

- корекційно-розвивальна (спрямована на формування соціальної готовності дитини до навчання в школі);

- координаційна (передбачає залучення інших фахівців галузі спеціальної освіти для роботи з дітьми та їх батьками);

- контролююча (спрямована на спостереження за дотриманням батьками рекомендацій фахівців галузі спеціальної освіти).
Цільовий складник відображає головне завдання, яке стоїть перед фахівцями галузі спеціальної освіти й батьками дітей із порушеннями інтелектуального розвитку - це сприяння в розвитку, подоланні вікових та особистісних проблем дошкільників. На основі результатів теоретичного аналізу соціальної ситуації розвитку дітей дошкільного віку з ПІР ПС та з урахуванням структурної моделі соціальної готовності до навчання нами було визначено такі завдання психологічного супроводу: діагностика та формування компетентності батьків дітей СДВ із ПІР ПС; діагностика та формування комунікативної компетентності соціальної готовності; діагностика та формування соціальної компетентності соціальної готовності.

Організаційно-процесуальний складник моделі включає експериментальні моделі: з діагностики й розвитку компетентності батьків дітей зазначеної категорії; з діагностики й формування соціальної готовності до навчання дітей СДВ із ПІР ПС у школі. Також умови, форми й методи, етапи: 1) планування психологічного супроводу; 2) початок психологічного супроводу; 3) здійснення психологічного супроводу; 4) завершення психологічного супроводу.

Завершальним складником нашої моделі психологічного супроводу виступає результат, який визначається двома взаємозумовленими рівнями: один передбачає сформованість компетентності батьків дітей СДВ із ПІР ПС у процесі реалізації психологічного супроводу; другий - сформованість соціальної готовності дітей старшого дошкільного віку з ПІР ПС до навчання, що призводить до успішної адаптації дитини в соціокультурному середовищі.

Висновки 3 проведеного дослідження. У нашому контексті психологічний супровід дітей старшого дошкільного віку з ПІР ПС має бути спрямований на вивчення особистісних особливостей дітей у його діагностичній частині, позитивної взаємодії з оточенням, розвитку довільної поведінки, зниження негативних емоційних переживань тощо - в його формувальній частині. Вважаємо, що представлена модель психологічного супроводу $€$ певним алгоритмом дій фахівців галузі спеціальної освіти в напрямах діагностичної та корекційно-розвивальної роботи з дітьми старшого дошкільного віку з ПІР ПС.

\section{ЛITEPATУРA:}

1. Битянова М.Р. Система развивающей работы школьного психолога. Психологический тренинг как форма развивающей работы. Школьный психолог. 2004. № 46. C. $12-15$.

2. Гречко Л.М. Психологічний супровід дітей молодшого шкільного віку з вадами психофрізичного розвитку в умовах інтегрованого навчання: автореср. дис. ... канд. психол. наук : 19.00.08. Київ, 2008. 20 с. 
3. Калініна Т.С. Психологічний супровід молодших підлітків із ЗПР на етапі адаптації до середньої освітньої ланки. Збірник наукових праць КамянецьПодільського національного університету імені Івана Огієнка. Серія: Соціально-педагогічна. 2011. Вип. 17 (1). С. 267-274

4. Кобильченко В.В. Базові сценарії занять 3 тренінгу педагогічної рефрлексії. Дефректологія (Особлива дитина: навчання і виховання). 2011. № 2. С. 32-38.

5. Краткий психологический словарь / под ред. А.В. Петровского, М.Г. Ярошевского. Москва : Политиздат, 1985. 156 с.

6. Миронова С.П., О.В. Гаврилов, М.П. Матвєєва Основи корекційної педагогіки: навчально-методич- ний посібник / За заг. ред. С.П. Миронової]. Кам'янець-Подільський : Кам'янець-Подільський національний університет імені Івана Огієнка, 2010. 264 с.

7. Сак Т.В. Диференційований підхід до навчання учнів з особливими освітніми потребами. Науковий часопис НПУ ім. М. П. Драгоманова. Серія 19: Корекційна педагогіка та спеціальна психологія. 2014. Вип. 26. С. 215-219.

8. Соколова Г.Б. Актуальні питання психолого-педагогічного супроводу сімей, які виховують дитину 3 обмеженими можливостями здоров'я. Збірник наукових праць Кам'янець-Подільського національного університету імені Івана Огієнка. Кам'янецьПодільський, 2016. Випуск 7. Том 1. С. 383-393. 